\title{
Effect of partial shading in grid connected solar PV system with FL Controller
}

\author{
K. Latha Shenoy ${ }^{1,3}$, C. Gurudas Nayak ${ }^{2}$, Rajashekar P Mandi ${ }^{3}$ \\ ${ }^{1}$ Department of Electrical and Electronics Engineering, NMAM Institute of Technology, Nitte \\ ${ }^{2}$ Department of Instrumentation \& Control Engineering, MIT, MAHE, Manipal \\ ${ }^{3}$ School of Electrical \& Electronics Engineering, REVA University, Bangalore
}

\section{Article Info}

Article history:

Received Jan 7, 2020

Revised Jan 15, 2021

Accepted Feb 10, 2021

\section{Keywords:}

Fuzzy controller

Intelligent controller

MPPT

Partial shading

Photovoltaics

VSC

\begin{abstract}
As conventional fossil fuel reserves shrink and the danger of climate change prevailing, the need for alternative energy sources is unparalleled. A smart approach to compensate the dependence on electricity generated by burning fossil fuels is through the power generation using grid connected PV system. Partial Shading on PV array affects the quantity of the output power in photovoltaic (PV) systems. To extract maximum power from PV under variable irradiance, variable temperature and partial shading condition, various MPPT algorithms are used. Incremental conductance and fuzzy based MPPT techniques are used for maximum power extraction from PV array. Basically $11 \mathrm{~kW}$ Solar PV system comprising of PV array coupled with an Inverter through a dc-dc converter is considered for the analysis and output of the inverter is supplied to the load through the LCL filter. An Intelligent controller for maximum power point tracking of PV power is designed. Also, a fuzzy controller for VSC is developed to improve the system performance. The above proposed design has been simulated in the Matlab Simulink and analyzed the system performance under various operating conditions. Finally, the performance is evaluated with IEEE 1547 standard for showing the effectiveness of the system.
\end{abstract}

This is an open access article under the CC BY-SA license.

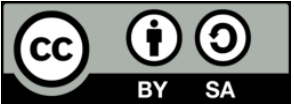

Corresponding Author:

K. Latha Shenoy

Departement of Electrical and Electronics Engineering

NMAM Institute of Technology

Nitte, Udupi District, Karnataka, India

Email: lathashenoy@nitte.edu.in

\section{INTRODUCTION}

Major global issues namely World Energy Crisis and Human Induced Climate change or global warming caused due conventional power generation, resulted in swing towards power extraction from renewable energy sources such as photovoltaic (PV) and wind generation systems, thereby replacing conventional power generation units. In India, the average annual solar energy incident on land area alone is about 5000 trillion kilowatt-hours because India gets about 300 clear sunny days in a year. The solar energy output received in a year exceeds the possible energy output of all the fossil fuel reserves in India [1]. Though solar energy is available free and abundantly in nature to meet the energy requirement, extracting it requires solar module whose initial investment cost is very high. Also, the efficiency of PV cell is low between 6-20\%. The monocrystalline PV cell has highest efficiency between 14-20\% [2]. Hence the maximum power point tracking algorithm is playing a very essential role in renewable energy sources for generating maximum power at various weather conditions. The solar photovoltaic system generates electricity when sunlight falls on modules. The sunlight irradiance is nonlinear in nature and varies time to 
time due to which PV modules unable to generate maximum power [3]. To extract the energy present in these renewable sources state-of-art power electronic systems are essential [4]. The PV system may perform power conversion in single stage or double stage of control operation. For single stage power conversion, inverter controller itself incorporate control of both MPPT and grid voltage. In the double stage conversion, a dc/dc converter used in the first stage and dc/ac inverter is connected in the second stage. The maximum power point tracking is done using the $\mathrm{dc} / \mathrm{dc}$ converter whereas $\mathrm{dc} / \mathrm{ac}$ inverter is used to produce the appropriate reference $\mathrm{dc}$ voltage for $\mathrm{dc}$ to ac conversion [5]. The inverter will convert DC voltage into three-phase sinusoidal voltages or currents which is then delivered to the grid in a grid-connected solar PV system or to the load in a stand-alone system [6]. The unpredictable and fluctuating nature of resource is major concerns of solar energy systems. Hence to overcome this issue, grid-connected renewable energy systems are accompanied by battery energy storage [7]. This paper is concerned with the design and study of a gridconnected three-phase solar PV system especially under partially shaded condition of PV arrays.

The total installed capacity of photovoltaic is over $30 \mathrm{GW}$ in 2019 , including both ground mounted and roof top solar system according to the "State wise installed solar power capacity" reports of Ministry of New and Renewable Energy, Govt. of India [8]. Shading can result in a large reduction in power output. Cells in modules are normally connected in series, so when one or several cells are shaded, the current output of the module will be reduced. If the module is part of an array, then the current output of the array will also be reduced [9]. Shading of the array can lead to irreversible damage. However, bypass diodes can be used to mitigate temporary shading. The combination of different distributed generation units and local loads forms a small self-sustaining power network which serves its local load. Generally, it can be operated in grid connected mode or grid isolated mode [10], [11]. Various controllers like PI controller, fuzzy controller is used for grid integration. The fuzzy controller will improve the system performance in case of grid connected PV system [12], [13]. This will result in lower cost, better efficiency and increased flexibility of power flow control. The lay out of the paper is organized as follows. Section II describes the Fuzzy based MPPT controller for PV system in order to track the maximum power output from the PV panel and fuzzy controller for VSC controller. Section III presents the proposed topology to integrate solar PV with the grid and its associated control system. Section IV describes the experimental results and analysis of the performance of the proposed system. Section V includes the conclusion of the paper.

\section{MPPT CONTROLLER FOR PV SYSTEM}

To extract maximum power from PV, the output resistance needs to be equal to the input resistance. To obtain sufficient input resistance, the duty cycle of the converter switch is required to adjust. The maximum power point tracking (MPPT) algorithm plays a very essential role in renewable energy sources for generating maximum power under various weather conditions. One of the most common MPPT techniques is the Hill Climbing or perturb and observe $(\mathrm{P} \& \mathrm{O})$ method. The conventional algorithms such perturb and observe $(\mathrm{P} \& \mathrm{O})$, incremental conductance (IC) used have limitations. To overcome this, soft computing method such as Fuzzy Logic, Neural Networks, Artificial Intelligence, Particle Swarm Optimization, are also proposed for solving the MPPT problem [14], [15]. In this paper, the fuzzy logic controller based MPPT algorithm has been developed and simulated in Matlab environment [16]. The overall structure of the proposed grid connected PV system is shown in Figure 1. Two fuzzy controllers are developed for the converters. The boost converter-based PV MPPT system has been developed in Matlab as shown in Figure 2. The specification about the module used for PV system is shown in Table 1.

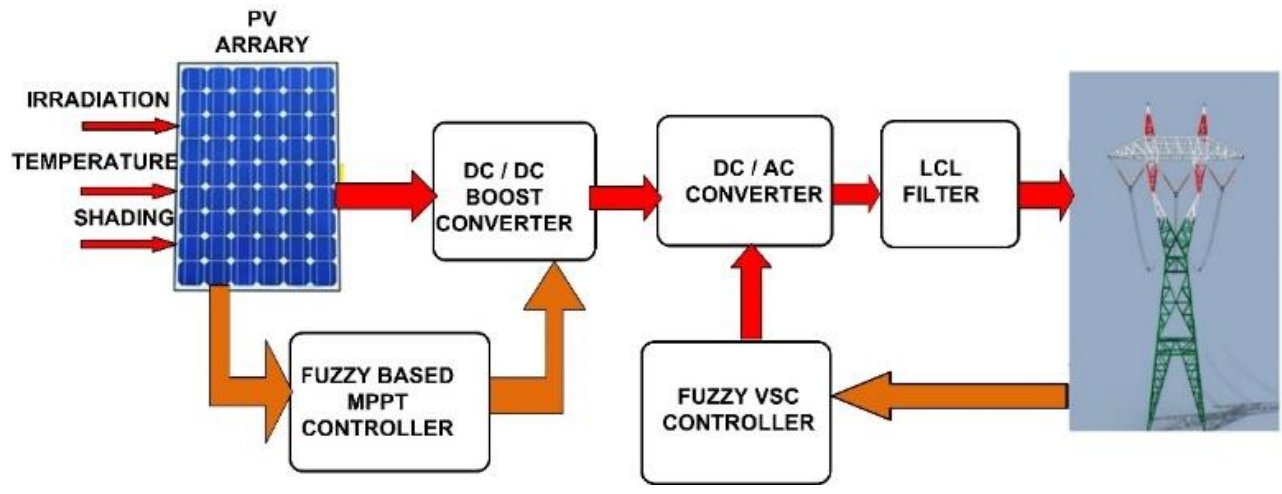

Figure 1. Block diagram of proposed grid connected PV System 
Table 1. Solar PV module specifications

\begin{tabular}{clc}
\hline SL No & \multicolumn{1}{c}{ Parameters } & Ratings \\
\hline 1 & Maximum power Pmp & $200 \mathrm{~W}$ \\
2 & O.C voltage & $30.8 \mathrm{~V}$ \\
3 & Voltage at maximum power point & $24.5 \mathrm{~V}$ \\
4 & Current at maximum power point & $8.16 \mathrm{~A}$ \\
5 & Parallel strings & 6 nos \\
6 & Series connections per string & 9 nos \\
\hline
\end{tabular}

\subsection{Design of fuzzy logic controller}

The fuzzy logic controller has been developed with two inputs and one output functions such as PV voltage, PV current and duty cycle of the PV boost converter as shown in Figure 2. The fuzzy PV voltage input membership function is classified three ranges such as low voltage (LV), medium voltage (MV) and high voltage (HV) [17]-[20]. The fuzzy PV current input membership function is classified three ranges such as low current (LI), medium current (MI) and high current (HI). The fuzzy duty cycle output membership function is classified three ranges such as low duty cycle (LD) medium duty cycle (MD) and high duty cycle (HD). The mamdani based fuzzy controller is used for PV MPPT as shown in Figure 3(a).

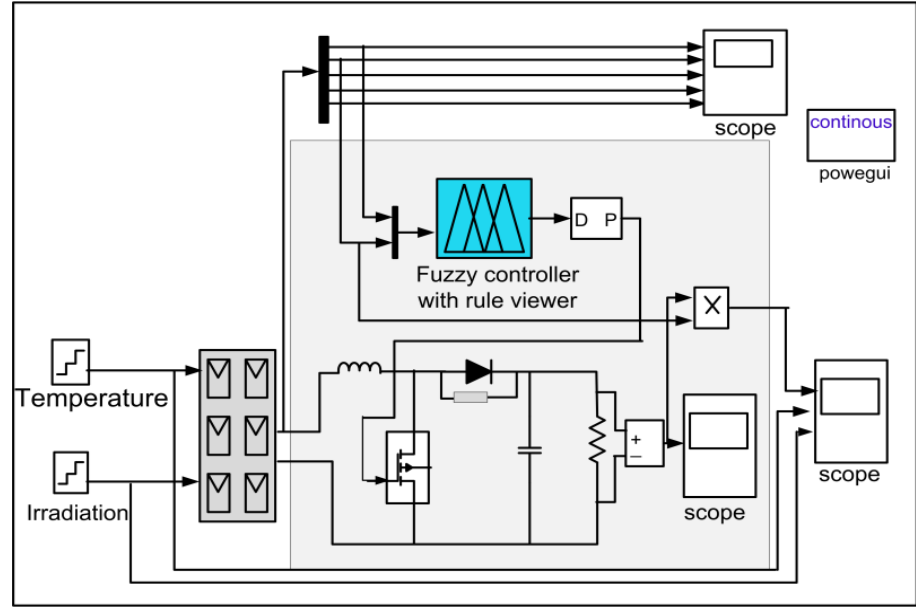

Figure 2. Fuzzy based MPPT controller simulation model of grid tie PV system

The fuzzy rule basis obtained as shown in Table 2. Figure 3(b) indicates the surface view of fuzzy MPPT controller.

Table 2. PV MPPT fuzzy rules basis

\begin{tabular}{cccc}
\hline Fuzzy membership & LI & MI & HI \\
\hline LV & HD & HD & HD \\
MV & HD & MD & MD \\
HV & MD & MD & LD \\
\hline
\end{tabular}

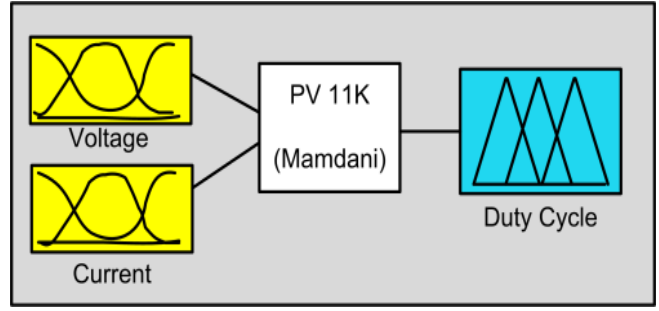

(a)

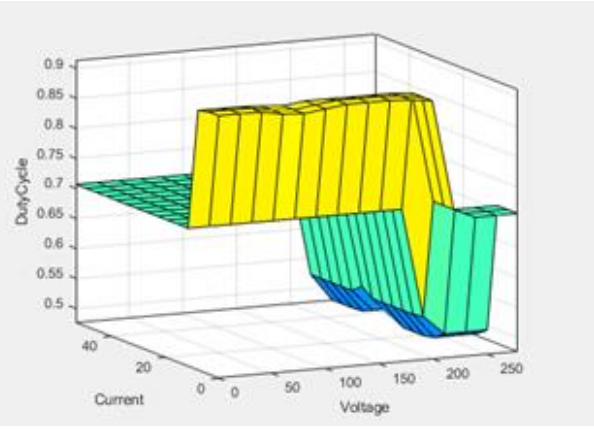

(b)

Figure 3. (a) Fuzzy based MPPT controller; (b) fuzzy rules surface system for MPPT controller

Effect of partial shading in grid connected Solar PV system using fuzzy controller (K. Latha Shenoy) 
The PV arrary performance under different irradiation and temperature is taken for the analysis. The Figure 4(a) shows the current versus voltage characteristic of the PV arrary for temperatures of $25^{\circ} \mathrm{C}, 45^{\circ} \mathrm{C}$, $55^{\circ} \mathrm{C}$ and $75^{\circ} \mathrm{C}$. It is observed that as temperature increases the open circuit voltage decreases whereas the short circuit current increases by small fraction. Figure 4(b) indicates the variation of power versus the arrary voltage under different temperature like $25^{\circ} \mathrm{C}, 45^{\circ} \mathrm{C}, 55^{\circ} \mathrm{C}$ and $75^{\circ} \mathrm{C}$. It is observed from the curve that power output from the panel decreses as the temperature of the PV panel increases. Hence it is essential to provide cooling for the panel inorder to obtain the desired output from the PV array.

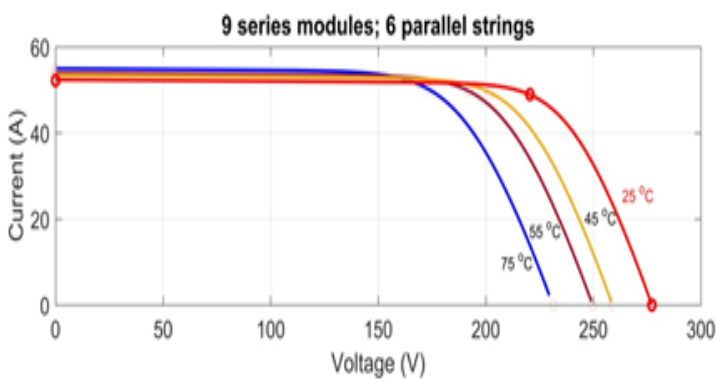

(a)

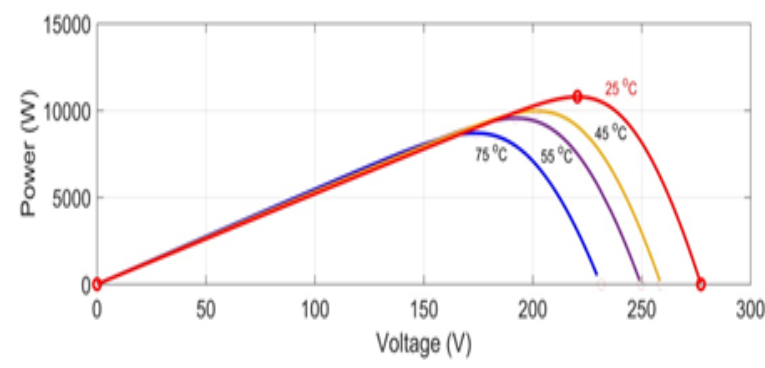

(b)

Figure 4. Solar PV array characteristics under variable temperature condition (a) current versus voltage, (b) power versus voltage $(\mathrm{P}-\mathrm{V})$

Figure 5(a) indicats the current versus voltage characteristic of the PV array under irradiation of $100 \mathrm{~W} / \mathrm{m}^{2}, 500 \mathrm{~W} / \mathrm{m}^{2}, 750 \mathrm{~W} / \mathrm{m}^{2}, 1000 \mathrm{~W} / \mathrm{m}^{2}$. The current produced by the PV cell decreses as the irradiation decreases. The PV generated current is $50 \mathrm{~A}$ for the irrdation of $1000 \mathrm{~W} / \mathrm{m}^{2}$. The Figure 5(b) indicates power versus voltage characteristic. As the irradiation received by the PV decreses, the yield of the $\mathrm{PV}$ array decreases. It produces power output of $11 \mathrm{KW}$ for the irradiation of $1000 \mathrm{~W} / \mathrm{m}^{2}$.

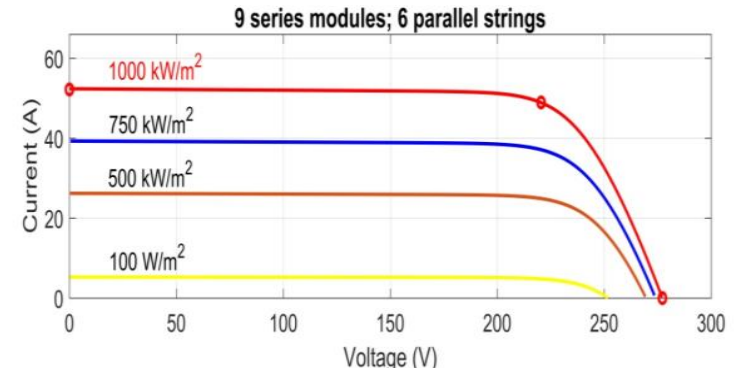

(a)

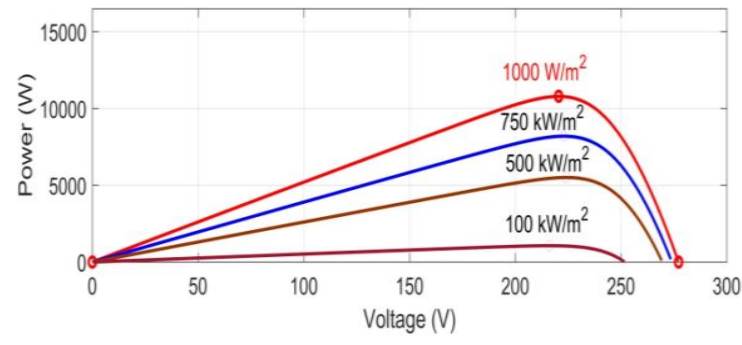

(b)

Figure 5. PV array characteristics under variable irradiance (a) I-V characteristics (b) P-V characteristics

\subsection{Design of Fuzzy Controller for VSC}

The current regulator for voltage source converter is developed using fuzzy logic controller with two inputs and two outputs functions. Input variables are referred as error values Id and Iq. The output variables are controlled Id and Iq. The error value of Id and Iq can be calculated by the difference between Id, Iq reference generated by voltage regulator and Id, Iq measured. The overall VSC controller structure is shown in Figure 6. The PLL block uses three phase voltage and current from the grid to generate the reference voltage required for the three-phase inverter [21]-[23]. 


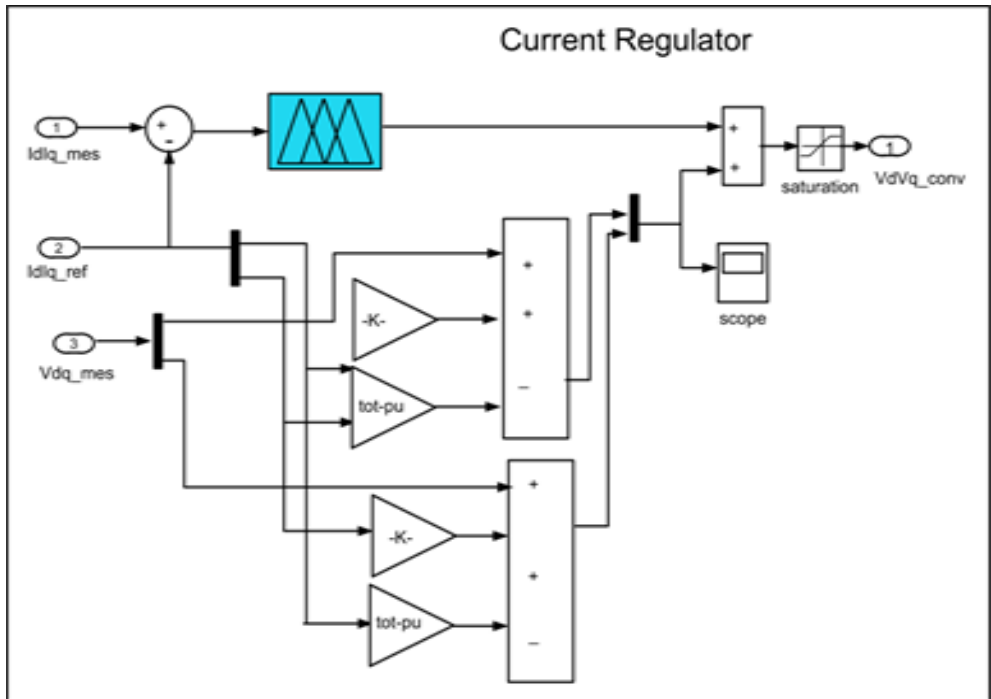

Figure 6. Fuzzy logic controllers for VSC

\section{GRID CONNECTED PV UNDER PARTIAL SHADING CONDITION}

The Figure 7 representes the simulation of PV system in matlab simulink carried out with fuzzy controllers. The proposed system consists of two PV arrays, each of $11 \mathrm{KW}$ ratings is considered for the performance analysis of grid connected PV system. The array PV1 is receiving normal irradiation whereas another PV array (PV2) is under shaded condition. Whenever there is surplus PV generation, the excess power is delivered to the grid after meeting the load requirement. At the same time during evening if the PV generation is not sufficienct the grid supplies the deficit power to meet the load requirement. This power flow is represented in the Figures 8 and 9.

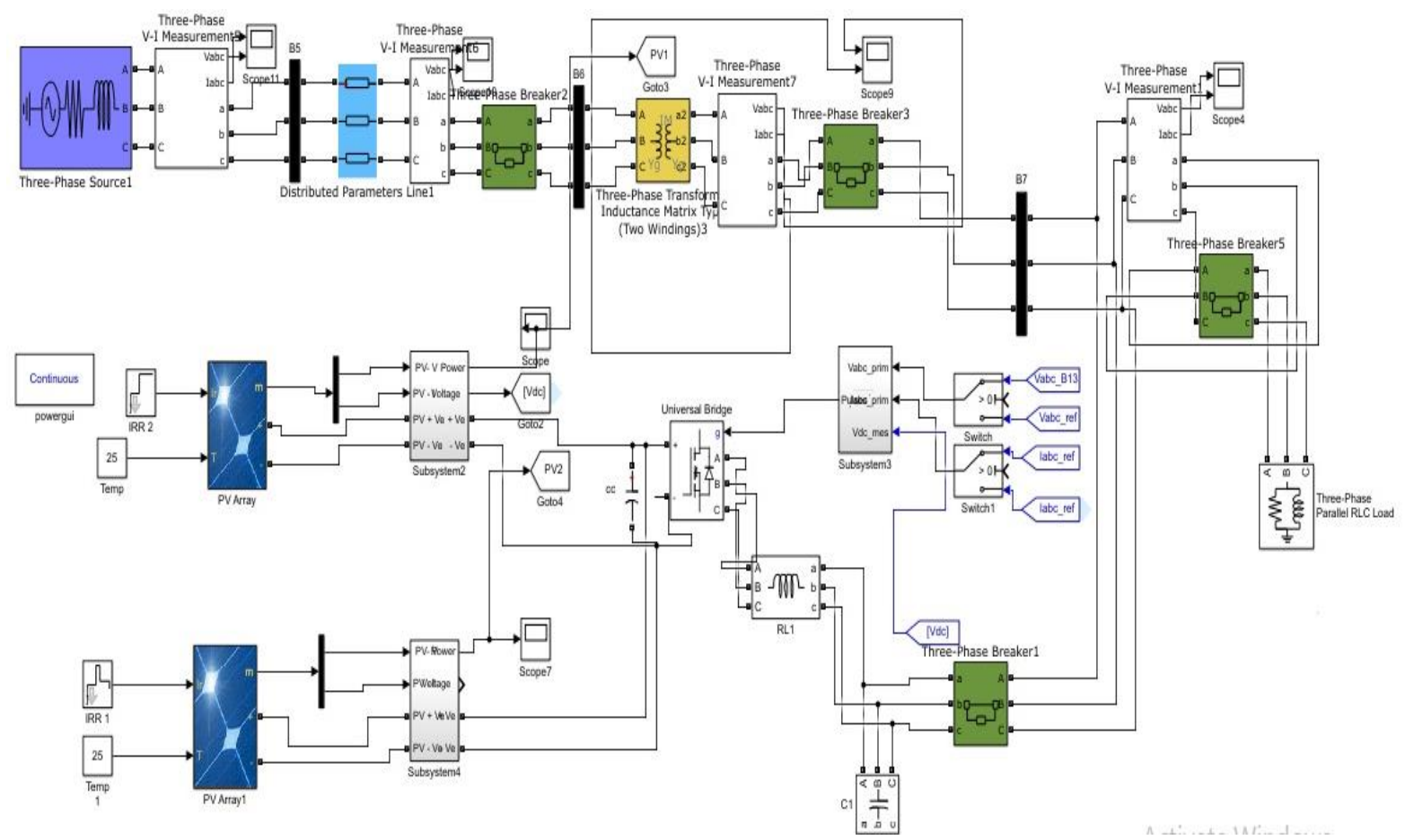

Figure 7. Simulation diagram for PV system under partial shading 

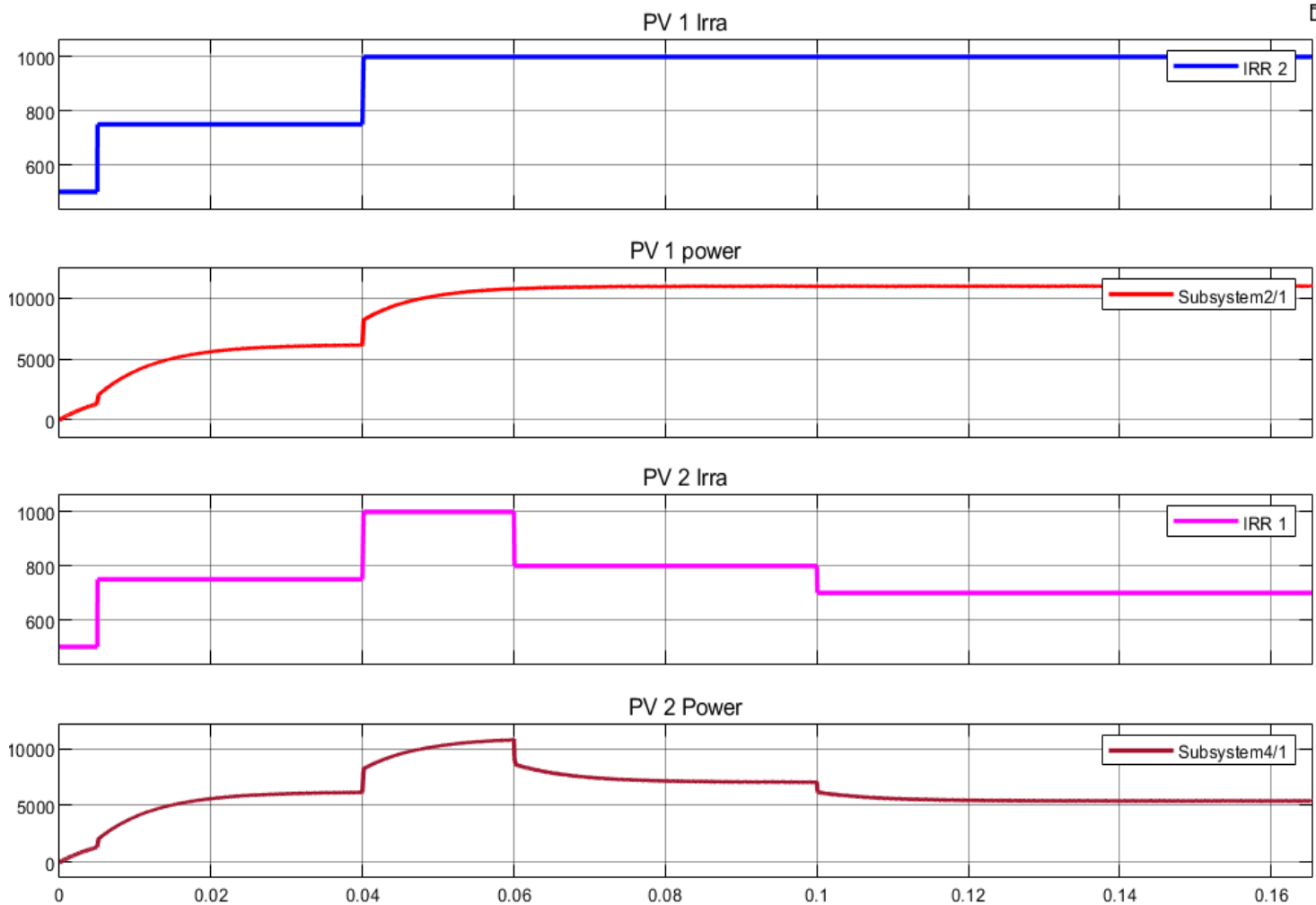

Figure 8. (a) Variation of irradiation for PV panel PV1, (b) total amount of power delivered by the panel PV1 for the corresponding irradiation, (c) variation of irradiation for PV panel PV2, (d) total power delivered under normal and partial shading condition by PV2

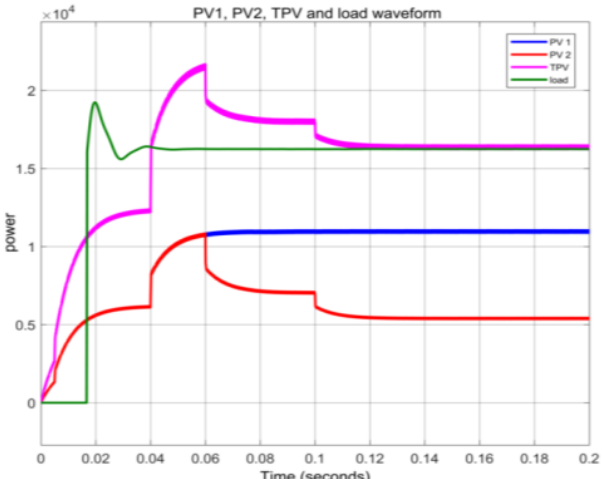

(a)

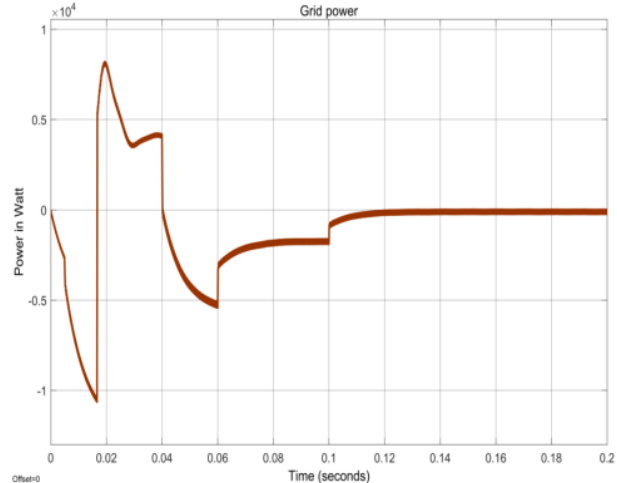

(b)

Figure 9. (a) Variation of PV under normal and shading conditions along with grid and load power requirement (blue line: PV 1 Power, Red line: PV 2 power, green line: load power and pink line: PV total power), and b) grid power variations for normal and partial shading condition

\section{RESULTS AND ANALYSIS}

At $t=0$, both panel PV1 and PV 2 will be receiving irradiation of $500 \mathrm{~W} / \mathrm{m} 2$ and hence able to generate power as represented in Figure 8 . At $t=0.004 \mathrm{sec}$, PV1 and PV2 generates total power of $3 \mathrm{~kW}$. Since no load is connected, the generated power will be delivered to the grid. It is shown with negative sign. At $\mathrm{t}=0.005 \mathrm{sec}$, irradiation varies from $500 \mathrm{~W} / \mathrm{m}^{2}$ to $750 \mathrm{~W} / \mathrm{m}^{2}$. Hence total of $5000 \mathrm{~W}$ was generated by both the PV panels together. Since load is not connected to the system, the generated power of $5 \mathrm{~kW}$ was supplied to the grid. At $\mathrm{t}=0.015 \mathrm{sec}$, the power generation capacity of both the PV panels were around 10 $\mathrm{kW}$. So total power of $10 \mathrm{~kW}$ was supplied to the grid. At $t=0.03 \mathrm{sec}$, load of around $16 \mathrm{~kW}$ is applied to 
the system. Now the generation is $12 \mathrm{~kW}$ was obtained for the given irradiation. In order to meet the load demand, there is deficit of $4 \mathrm{~kW}$ power which will be drawn from the grid. At $t=0.04 \mathrm{sec}$, further irradiation increases to $1000 \mathrm{~W} / \mathrm{m}^{2}$, generating the power of $8 \mathrm{~kW}$ each. Hence total power generated by the $\mathrm{PV}$ panel is $16 \mathrm{~kW}$. Under this condition no power is delivered to the gird, as generation and demand both are equal. At $t=0.05 \mathrm{sec}$, total power generation is $20 \mathrm{~kW}$. The additional excess power of $4000 \mathrm{~W}$ was then fed to the grid. At $t=0.06 \mathrm{sec}$, the solar panel PV2 was under partial shading effect. It receives irradiation of $800 \mathrm{~W} / \mathrm{m}^{2}$. Under this partial shading condition, it generates reduced power of $8000 \mathrm{~W}$. Therefore, total power $19 \mathrm{~kW}$ is generated. Hence excess power $3 \mathrm{~kW}$ is delivered back to the grid. It will continue till 0.1 $\mathrm{sec}$ at which further irradiation on PV2 falls to $700 \mathrm{~W} / \mathrm{m}^{2}$ due to partial shading. The total generated power now is $18 \mathrm{~kW}$. The excess power of $2 \mathrm{~kW}$ is sent to the grid [24]-[26]. Table 3 gives the details of PV power generated by both panels for different irradiation. Also, it gives the details about the power flow between load and the grid.

Table 3. Power distribution among PV, Grid and load for different irradiation

\begin{tabular}{|c|c|c|c|c|c|c|c|c|}
\hline Power & $0.004 \mathrm{Sec}$ & $0.005 \mathrm{Sec}$ & $0.015 \mathrm{Sec}$ & $0.03 \mathrm{Sec}$ & $0.04 \mathrm{Sec}$ & $0.05 \mathrm{Sec}$ & $0.06 \mathrm{Sec}$ & $0.1 \mathrm{Sec}$ \\
\hline PV1 Irradiation & $500 \mathrm{~W} / \mathrm{m}^{2}$ & $750 \mathrm{~W} / \mathrm{m}^{2}$ & $750 \mathrm{~W} / \mathrm{m}^{2}$ & $750 \mathrm{~W} / \mathrm{m}^{2}$ & $1000 \mathrm{~W} / \mathrm{m}^{2}$ & $1000 \mathrm{~W} / \mathrm{m}^{2}$ & $1000 \mathrm{~W} / \mathrm{m}^{2}$ & $1000 \mathrm{~W} / \mathrm{m}^{2}$ \\
\hline PV1 Power & $1500 \mathrm{~W}$ & $2500 \mathrm{~W}$ & $5000 \mathrm{~W}$ & $6000 \mathrm{~W}$ & $8000 \mathrm{~W}$ & $10000 \mathrm{~W}$ & $11000 \mathrm{~W}$ & $11000 \mathrm{~W}$ \\
\hline PV2 Irradiation & $500 \mathrm{~W} / \mathrm{m}^{2}$ & $750 \mathrm{~W} / \mathrm{m}^{2}$ & $750 \mathrm{~W} / \mathrm{m}^{2}$ & $750 \mathrm{~W} / \mathrm{m}^{2}$ & $1000 \mathrm{~W} / \mathrm{m}^{2}$ & $1000 \mathrm{~W} / \mathrm{m}^{2}$ & $800 \mathrm{~W} / \mathrm{m}^{2}$ & $700 \mathrm{~W} / \mathrm{m}^{2}$ \\
\hline PV2 power & $1500 \mathrm{~W}$ & $2500 \mathrm{~W}$ & $5000 \mathrm{~W}$ & $6000 \mathrm{~W}$ & $8000 \mathrm{~W}$ & $10000 \mathrm{~W}$ & $8000 \mathrm{~W}$ & $7000 \mathrm{~W}$ \\
\hline Total PV Power & $3000 \mathrm{~W}$ & $5000 \mathrm{~W}$ & $10000 \mathrm{~W}$ & $12000 \mathrm{~W}$ & $16000 \mathrm{~W}$ & $20000 \mathrm{~W}$ & $19000 \mathrm{~W}$ & $18000 \mathrm{~W}$ \\
\hline Load Power & $0 \mathrm{~W}$ & $0 \mathrm{~W}$ & $0 \mathrm{~W}$ & 16000W & $16000 \mathrm{~W}$ & $16000 \mathrm{~W}$ & $16000 \mathrm{~W}$ & $16000 \mathrm{~W}$ \\
\hline Grid Power & $-3000 \mathrm{~W}$ & $-5000 \mathrm{~W}$ & $-10000 \mathrm{~W}$ & $+4000 \mathrm{~W}$ & $0 \mathrm{~W}$ & $-4000 \mathrm{~W}$ & $-3000 \mathrm{~W}$ & $-2000 \mathrm{~W}$ \\
\hline
\end{tabular}

Figure 9(a) indicates the variations in power delivered by PV panels, PV1 and PV2 under normal and partial shading conditions. The load of $16 \mathrm{~kW}$ is applied at time $t=0.016 \mathrm{sec}$. The Figure 9 (b) shows the corresponding variation in the grid power during various time intervals. During the period 0.04 to $0.1 \mathrm{sec}$, the PV generation is less than the demand. Hence grid supports the additional load. For the analysis of power flow, sign convention for grid power is taken as represented below. Positive sign indicates power is supplied by the grid to meet the load demand. Negative sign indicates excess generated power is given back to the grid. The Table 4 shows the comparison between various controllers used for the PV system.

Table 4. Comparative table

\begin{tabular}{ccc}
\hline Profile & \multicolumn{2}{c}{ Total Harmonic Distortion (THD) } \\
& PI & Fuzzy \\
\hline Voltage & $2.39 \%$ & $1.28 \%$ \\
Current & $13.6 \%$ & $4.79 \%$ \\
\hline
\end{tabular}

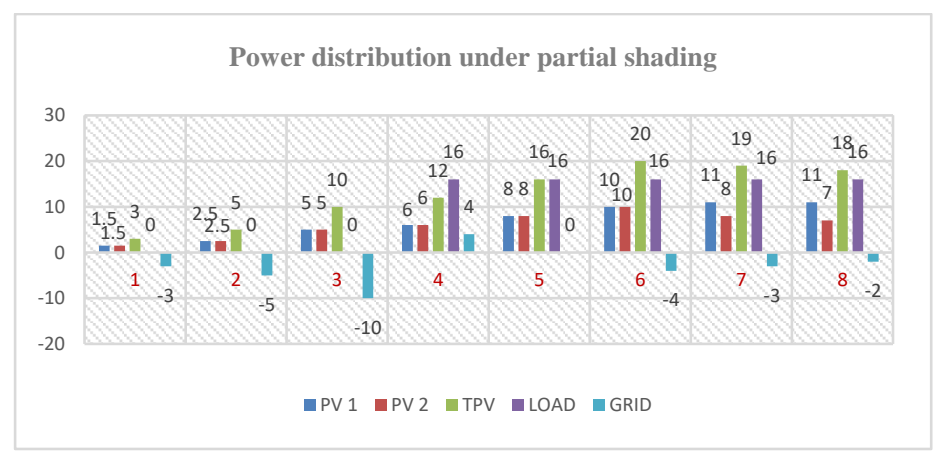

Figure 10. Bar chart of power exchange between PV, load and grid 


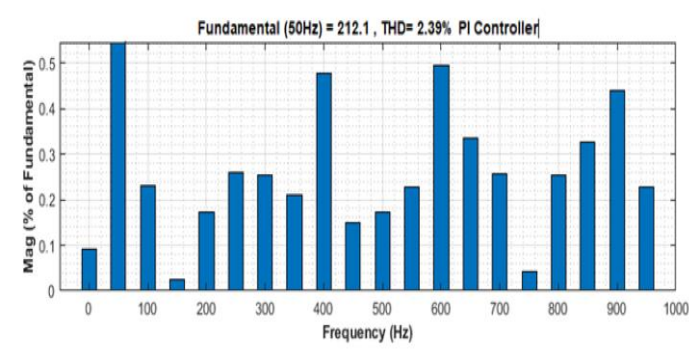

(a)

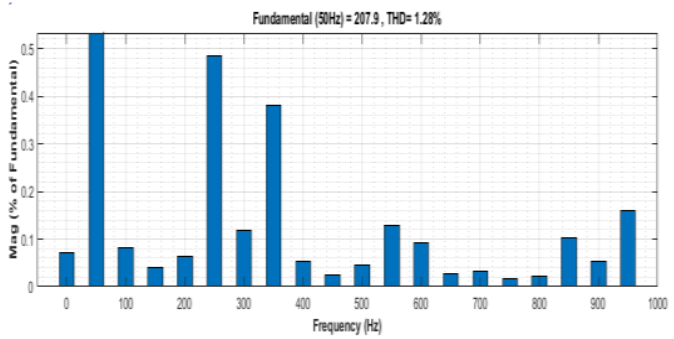

(c)

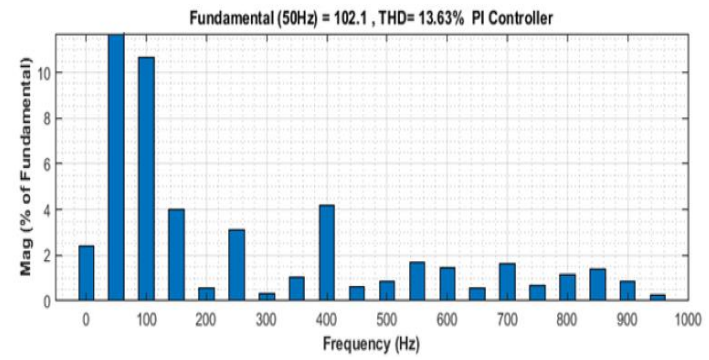

(b)

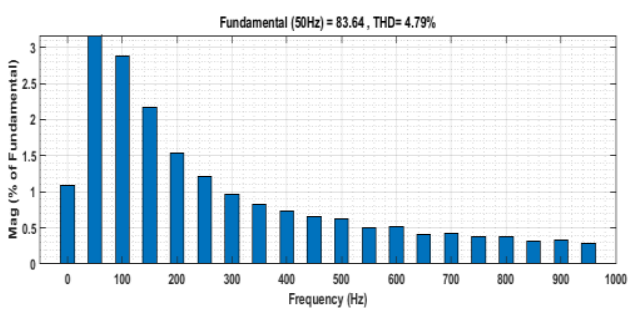

(d)

Figure 11. (a) Voltage THD waveform with PI controller, (b) current THD waveform with PI controller,

(c) voltage THD waveform with fuzzy controller, (d) current THD waveform with fuzzy controller.

\section{CONCLUSION}

This paper deals with the modeling of solar PV system under variable irradiance, variable temperature and partial shading condition of the array. The performance analysis of the PV system under partial shading condition for grid connected PV system is done. The fuzzy controller has been developed for maximum power point tracking for $11 \mathrm{~kW}$ photovoltaic power systems under partial shaded condition. Its performance under load condition is verified. The proposed PV system for grid integration has been simulated in matlab simulink and a fuzzy controller for grid synchronizing of PV system into the power grid is developed. Finally, the proposed model simulation results are analyzed with different operating conditions and evaluated with IEEE 1547 standard for proving the effectiveness system. In PI controller-based systems, the total harmonic distortion values for load voltage and current are measured and presented in Figures 11(a) and 11(b) respectively. The THD values of voltage and current for the fuzzy based system are $1.28 \%$ and $4.79 \%$ as represented in the Figures $11(\mathrm{c})$ and (d) respectively. Based on the standard value for grid integration of renewable energy sources, THD values less than $5 \%$ is acceptable. The load voltage and current waveforms are sinusoidal.

\section{ACKNOWLEDGEMENTS}

Authors are very grateful to management of NMAM Institute of Technology Nitte, Udupi and REVA University, Bengaluru for providing resources to conduct this research work.

\section{REFERENCES}

[1] "Physical Progress (Achievements)," Ministry of New and Renewable Energy, Govt. of India, 2014.

[2] M. Karimi, H. Mokhlis, K. Naidu, S. Uddin, and A. H. A. Bakar, "Photovoltaic penetration issues and impacts in distribution network-A review," Renewable and Sustainable Energy Reviews, vol. 53, pp. 594-605, 2016.

[3] IEEE Standard for, "Interconnecting Distributed Resources with Electric Power Systems," IEEE Standard 1547, 2003, pp. 1-16.

[4] Y. K., Wu. Jhih-Hao Lin and Huei-Jeng Lin, "Standards and Guidelines for Grid-connected Photovoltaic Generation Systems: A Review and Comparison," IEEE Transactions on Industry Applications, vol. 53, no. 4, pp. 3205-3216, 2017.

[5] Bana, S. and Saini R. P., "Experimental investigation on power output of different photovoltaic array configurations under uniform and partial shading scenarios," Energy, vol. 127, pp. 438-453, 2017. 
[6] A. Yazdani and P. P. Dash, "A control methodology and characterization of dynamics for a photovoltaic (PV) system interfaced with a distribution network," IEEE Transactions on Power Delivery, vol. 24, no. 3, pp. 1538-1551, 2009.

[7] X. Xiong, Chi K. Tse, and X. Ruan, "Bifurcation Analysis of Standalone Photovoltaic Battery Hybrid Power System," IEEE Transactions on Circuits and Systems I: Regular Papers, vol. 60, no. 5, pp. 1354-1365, 2013.

[8] "State wise installed solar power capacity," reports of Ministry of New and Renewable Energy, Govt. of India.

[9] S. Choudhury and P. K. Rout, "Adaptive Fuzzy Logic Based MPPT Control for PV System under Partial Shading Condition," International Journal of Renewable Energy Research-IJRER, vol. 5, no. 4, pp. 1252-1263, 2015.

[10] T Hemanand, N.P. Subramaniam, \& M. Venkateshkumar, "Comparative analysis of intelligent controller based microgrid integration of hybrid PV/wind power system," Journal of Ambient Intelligence and Humanized Computing, 2018.

[11] H. Zheng, S. Li, R. Challoo, J. Proano, "Shading and bypass diode impacts to energy extraction of PV arrays under different converter configurations," Renewable Energy, vol. 68, pp. 58-66, 2014.

[12] O.P. Yadav, J. Kaur, N.K Sharma and Y. R. Sood, "Renewable Energy Management in Multi-microgrid Under Deregulated Environment of Power Sector," Applications of Artificial Intelligence Techniques in Engineering, vol. 698, pp. 289-302, 2019.

[13] G. Raman, J. C. Peng and W. Xiao, "Bridging the transition to DC distribution: A hybrid microgrid for residential apartments," 2017 IEEE Innovative Smart Grid Technologies - Asia (ISGT-Asia), Auckland, 2017, pp. 1-6.

[14] Ferraro P, Crisostomi E, Raugi M, Milano F, "Analysis of the impact of microgrid penetration on power system dynamics,” IEEE Transactions on Power Systems, vol. 32, no. 5, pp. 4101-4109, 2017.

[15] D. Sera, L. Mathe, T. Kerekes, "On the parturb-and-observe and incremental conductance MPPT methods for PV systems," IEEE Journal of Photovoltaics, vol. 3, no. 3, pp. 1070-1078, 2013.

[16] M. A. M. Ramli, S. Twaha, K. Ishaque and Y. A. Al-Turki, "A review on maximum power point tracking for photovoltaic systems with and without shading conditions," Renewable and Sustainable Energy Reviews, vol. 67, pp. 144-159, 2017.

[17] R. Cakmak, I. H. Altas and A. M. Sharaf, "Modeling of FLC-Incremental based MPPT using DC-DC boost converter for standalone PV system," 2012 International Symposium on Innovations in Intelligent Systems and Applications, Trabzon, 2012, pp. 1-5.

[18] K.L. Shenoy, C.G. Nayak and R.P. Mandi, "Performance analysis of SPWM and SVPWM three phase voltage source inverter," International Journal of Control Theory and Applications, vol. 9, no. 21, pp. 307-314, 2016.

[19] G. Anandhakumar, M. Venkateshkumar and P. Shankar, "Intelligent controller based MPPT method for the Photovoltaic power system," 2013 International Conference on Human Computer Interactions (ICHCI), Chennai, 2013, pp. 1-6.

[20] H. Zhao, Q. Wu, C. Wang, L Cheng and C.N. Rasmussen, "Fuzzy Logic based Coordinated Control of Battery Energy Storage System and Dispatchable Distributed Generation for Microgrid," Journal of Modern Power Systems and Clean Energy, vol. 3, no. 3, pp. 422-428, 2015.

[21] C. Cai, H. Liu, H. Zheng, F. Chen, L. Deng and Q. Xu, "Microgrid multi-source coordination optimal control based on multi-scenarios analysis," The Journal of Engineering, vol. 2017, no. 13, pp. 1457-1461, 2017.

[22] I. U. Nutkani, L. Meegahapola, L. P. C. Andrew and F. Blaabjerg, "Autonomous power management for interlinked AC-DC microgrids," CSEE Journal of Power and Energy Systems, vol. 4, pp. 11-18, 2018.

[23] S. Shrivastava, B. Subudhi and S. Das, "Distributed voltage and frequency synchronization control scheme for islanded inverter-based microgrid," IET Smart Grid, vol. 1, no. 2, pp. 48-56, 2018.

[24] Y. Wang, L. Ding and N. Li, "The application of fuzzy parameters self-tuning PID controller in MPPT of photovoltaic power system," Proceedings 2011 International Conference on Transportation, Mechanical, and Electrical Engineering (TMEE), Changchun, 2011, pp. 1129-1132.

[25] K.L. Shenoy, C.G. Nayak and R. P. Mandi, "Fuzzy Controller Based Grid Integration of Hybrid Solar Photovoltaic and DFIG Wind Energy System to Improve Power Quality," Applied Mathematics \& Information Sciences, vol. 13, no. S1, pp. 447-457, 2019.

[26] A. Q. Al-Shetwi, M A Hannan, K P Jern, A. A. Alkahtani and A. E. PG Abas, "Power Quality Assessment of GridConnected PV System in Compliance with the Recent Integration Requirements," Electronics, vol. 9, no. 2, p, 366, 2020.

\section{BIOGRAPHIES OF AUTHORS}

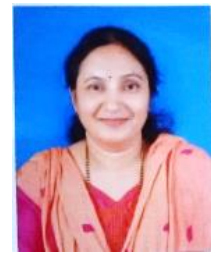

K. Latha Shenoy is presently working as assistant professor, Department of Electrical \& Electronics engineering, NMAM Institute of Technology, Nitte. She received her B.E. degree in Electrical \& Electronics Engineering from Mangalore University in 1996. She has 15 years of teaching experience and 4 years of industrial experience. She has published more than 16 technical papers in National, International Conferences and Journals. She received M. Tech degree in digital Electronics and Advanced communication from Manipal Institue of Technology, Manipal. Her research interests include renewable energy systems, power electronics, control systems. 


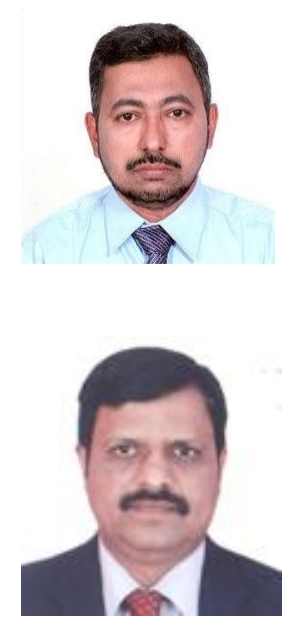

Dr. C Gurudas Nayak received his B.E. in Instrumentation Technology in 1988 from Gulbarga University, Gulbarga India and M.S.in Communication Engineering in the year 1996 from NewPort University, USA and PhD from MAHE, Manipal India in the year 2008. He has 30 years of Industrial /teaching experiences and published 100 papers in International, National Conferences and journals. He is currently working as a Professor in the Instrumentation and Control Engineering Department, Manipal Institute of technology, Manipal University, Manipal. His research interests include of Communication Networks, Instrumentation and Transducers and Mobile Telephone Systems.

Dr. Rajashekar P. Mandi is presently working as Director of School of Electrical Engineering, REVA University, Bangalore. Before joining REVA University, he worked in Central Power Research Institute, Bangalore for more than 26 years in research. He received M. Tech. degree in Energy Systems Engineering from Visweswaraiah Technological University, Belgaum with $3^{\text {rd }}$ rank and Ph. D in Power and Energy from NITK, Surathkal through research. He is a professional member of IEEE. He is accredited energy auditor from Bureau of Energy Efficiency (BEE), Govt. of India. He is presently chairman of Society for Energy Efficiency \& Manager (SEEM) Karnataka Chapter. 